\title{
Recovery of Valuable Materials from the Waste Crystalline-Silicon Photovoltaic Cell and Ribbon
}

\author{
Wei-Sheng Chen ${ }^{1}{ }^{D}$, Yen-Jung Chen ${ }^{1, *}$, Cheng-Han Lee ${ }^{1, *} \mathbb{D}$, Yi-Jin Cheng ${ }^{1}$, Yu-An Chen ${ }^{1}$, Fan-Wei Liu ${ }^{2}$, \\ Yi-Chung Wang ${ }^{2}$ and Yu-Lun Chueh ${ }^{2}$ \\ 1 Department of Resources Engineering, National Cheng Kung University, No. 1, Daxue Rd., East Dist., \\ Tainan City 701401, Taiwan; kenchen@mail.ncku.edu.tw (W.-S.C.); stevecheng44@gmail.com (Y.-J.C.); \\ evan860102@gmail.com (Y.-A.C.) \\ 2 Department of Materials Science and Engineering, National Tsing Hua University, No. 101, Section 2, \\ Kuang-Fu Road, Hsinchu 30013, Taiwan; gundamnewtype@hotmail.com (F.-W.L.); \\ ycw10208@gmail.com (Y.-C.W.); ylchueh@mx.nthu.edu.tw (Y.-L.C.) \\ * Correspondence: n46084167@ncku.edu.tw (Y.-J.C.); n48091013@gs.ncku.edu.tw (C.-H.L.)
}

check for updates

Citation: Chen, W.-S.; Chen, Y.-J.; Lee, C.-H.; Cheng, Y.-J.; Chen, Y.-A.; Liu, F.-W.; Wang, Y.-C.; Chueh, Y.-L. Recovery of Valuable Materials from the Waste Crystalline-Silicon Photovoltaic Cell and Ribbon. Processes 2021, 9, 712. https:// doi.org/10.3390/pr9040712

Academic Editors: Alazne Gutiérrez and Roberto Palos

Received: 1 April 2021

Accepted: 14 April 2021

Published: 17 April 2021

Publisher's Note: MDPI stays neutral with regard to jurisdictional claims in published maps and institutional affiliations.

Copyright: (c) 2021 by the authors. Licensee MDPI, Basel, Switzerland. This article is an open access article distributed under the terms and conditions of the Creative Commons Attribution (CC BY) license (https:/ / creativecommons.org/licenses/by/ $4.0 /)$.

\begin{abstract}
With the dramatic increase of photovoltaic (PV) module installation in solar energy-based industries, the methods for recovering waste solar generators should be emphasized as the backup of the PV market for environmental protection. Crystalline-silicon accounts for most of the worldwide PV market and it contains valuable materials such as high purity of silicon (Si), silver (Ag), copper $(\mathrm{Cu})$, tin $(\mathrm{Sn})$, and lead $(\mathrm{Pb})$. This study can provide an efficient recycling process for valuable materials resourced from waste crystalline-silicon PV module, including Si in the PV cell, and Ag, $\mathrm{Cu}, \mathrm{Pb}, \mathrm{Sn}$, in PV ribbon. As tempered glass and Ethylene Vinyl Acetate (EVA) resin were removed, the module was separated into two materials, PV ribbon and PV cell. For PV cell purification, Si with purity at $99.84 \%$ was recovered by removing impurities such as aluminum ( $\mathrm{Al}$ ) and Ag by two-step leaching and dissolving the impurities. For PV ribbon recovering, purified metal or metal oxide was obtained through the processes of leaching/polishing, extraction, and chemical precipitation. In the polishing process, $99.5 \%$ of copper wire was collected. The purities of final products are $99.7 \%$ for $\mathrm{CuO}, 99.47 \%$ for $\mathrm{PbO}, 99.68 \%$ for $\mathrm{SnO}_{2}$, and $98.85 \%$ for $\mathrm{Ag}$ respectively.
\end{abstract}

Keywords: end-of-life PV module; hydrometallurgy; metal separation; recycling

\section{Introduction}

Crystalline-silicon (c-Si) solar cell has been considered as an excellent generator owing to its abundant resource, stable oxidant, insolubility from water, etc. [1]. Therefore, the installation of the c-Si Photovoltaic (PV) module always took 90\% of the PV market, and the output of the PV module was 97.081 GW in 2019 [2]. However, the more production produced, the more end-of-life PV modules wasted. The waste panels will become an inevitable waste issue. According to the International Renewable Energy Agency (IRENA) report, approximately 6 million tons of PV waste will accumulate in 2050 [3]. Although the earth contained a great amount of silicon, the high purity of silicon is still expensive and taking a part in semiconductor industrials, steel mills, etc. Silver, copper, and tin are also widely used as critical materials from the technology industries. The toxic metal, lead, containing in the module will cause damage to the environment [4]. Hence, to treat and recycle the waste c-Si PV module, a separation and recovery process of silicon $(\mathrm{Si})$, silver $(\mathrm{Ag})$, copper $(\mathrm{Cu})$, tin $(\mathrm{Sn})$, and lead $(\mathrm{Pb})$ from the waste commercial c-Si modules must be studied.

Silicon purification methods in PV cells have been studied. After dismantling, the PV module was separated into two parts, the PV cell and the PV ribbon. The solar cell was soaked in nitric acid or aqua reagent to leach metallic components such as silver (Ag), aluminum (Al), and filter silicon into high purity. In the purification process, PV cells undergo several layers such as p-n junction, antireflection layer, texturization, and aluminum back 
surface should be removed from silicon for purification. According to the period research, it can be easily divided into two types of reagent ways to purify PV silicon: That containing hydrofluoric acid [5-11] or not [12-16]. Because HF was indicated as a highly corrosive acid, this study prefers the method without HF. PV ribbons contain most of the metal in the PV module, but there is little PV ribbon recovering research. PV ribbon looks like the wire what carried the electrical energy produced by solar cells. Lee et al. [17] separated PV ribbon by melting the coating layer composed of tin and lead and separate copper layer; then used the thermal process under a low atmosphere with $\mathrm{CH}_{4}$ to purify Copper, and the purity of $\mathrm{Cu}$ after physical treatment was $99.5 \%$. Kim et al. [18] oxidized the $\mathrm{Pb}-\mathrm{Sn}$ alloy layer of PV Ribbon and used ball milling to separate copper and oxide layer. The other research leached $\mathrm{Pb}$-free $\mathrm{PV}$ ribbon by $\mathrm{HCl}$ and $\mathrm{HNO}_{3}$ then separated it by precipitation and electrochemical. Moon et al. [19] showed a recycling process by leaching $\mathrm{Sn}$ by $\mathrm{HCl}$ and separated $\mathrm{Cu}$ by adding Sn powder to reductive copper ions and copper metals. After the leaching process, this research used tributyl phosphate (TBP) to extract $\mathrm{Sn}$ from the leach solution, and $<1 \%$ of $\mathrm{Pb}$ was extracted. Jung B. et al. [12] employed nitric acid and potassium hydroxide as the leaching regia to leach metallic components, then extracted copper with LIX84-I. Most of the research involves leaching all of the ribbon's components with reagent. However, due to the structure of the PV ribbon, it is possible to polish the surface before leaching. Our research has therefore focused on silicon and raw-metal recovery. $\mathrm{Si}, \mathrm{Ag}, \mathrm{CuO}, \mathrm{PbO}$, and $\mathrm{SnO}_{2}$ were obtained as the final products in this research.

In this study, the waste of the c-Si PV module was immersed in toluene to inflate the Ethylene Vinyl Acetate (EVA) resin between the tempered glass and the PV cell. The inflated EVA resin can help separate the tempered glass and the back sheet from the cell. EVA resin was calcinated through furnace in my previous research [20], and the module was separated into two parts, PV ribbon and PV cell. In the silicon purification part, the PV cell was leached by nitric acid and potassium hydroxide continuously. The concentration of reagent, liquid-solid ratio, reaction times, and temperature were investigated to optimize the method. In the ribbon separation part, the ribbon was treated in both chemical and physical methods to polish the surface. After previous treatment, metallic components were leached by hydrochloride and separated through TBP and LIX984N reagent, a 1:1 volume blend of 5-nonylsalicylaldoxime and 2-hydroxy-5-nonylacetophenone oxime. Finally, the separated metallic ion liquid was precipitated and calcinated to obtained $\mathrm{Ag}, \mathrm{CuO}, \mathrm{PbO}$, and $\mathrm{SnO}_{2}$. The ion concentration in the liquid of leaching and extraction process was investigated by inductively coupled plasma optical emission spectrometry (ICP-OES, PerkinElmer optima 2100 DV; Varian, Vista-MPX, PerkinElmer, Waltham, Massachusetts State, America) and the characteristic analyst of the final product was investigated by X-ray diffraction (XRD, Haoyuan DX-2000).

\section{Materials and Methods}

\subsection{Materials}

The waste c-Si PV module used in this study was sliced from the commercial waste which was scrapped in Typhoon Meranti. The sliced panel was a square shape with $10 \mathrm{~cm} \times 10 \mathrm{~cm}$. The module consists of aluminum frame, tempered glass, c-Si cell, and ribbon (Figure 1), and the mass fraction of the module are $14.9 \%, 70.8 \%, 3.3 \%$, and 1.1\%, respectively. Cells contained silicon wafer, silver, and aluminum screen-printed electrodes. The ribbon was coated with $\mathrm{Pb}-\mathrm{Sn}$ solder to prevent oxidizing. The mass fraction of PV cells and ribbons are summarized in Table 1.

Table 1. The composition of the PV cell and the ribbon.

\begin{tabular}{cccccc}
\hline \multirow{2}{*}{ PV Cell } & Element & $\mathrm{Si}$ & $\mathrm{Al}$ & $\mathrm{Ag}$ & $\mathrm{Bi}$ \\
\cline { 2 - 6 } & $\mathrm{wt} \%$ & $93.38 \%$ & $5.25 \%$ & $0.91 \%$ & $0.011 \%$ \\
\hline \multirow{2}{*}{ PV Ribbon } & Element & $\mathrm{Cu}$ & $\mathrm{Pb}$ & $\mathrm{Sn}$ & $\mathrm{Ag}$ \\
\cline { 2 - 6 } & $\mathrm{wt} \%$ & $79.6 \%$ & $5 \%$ & $8.64 \%$ & $3.02 \%$ \\
\hline
\end{tabular}




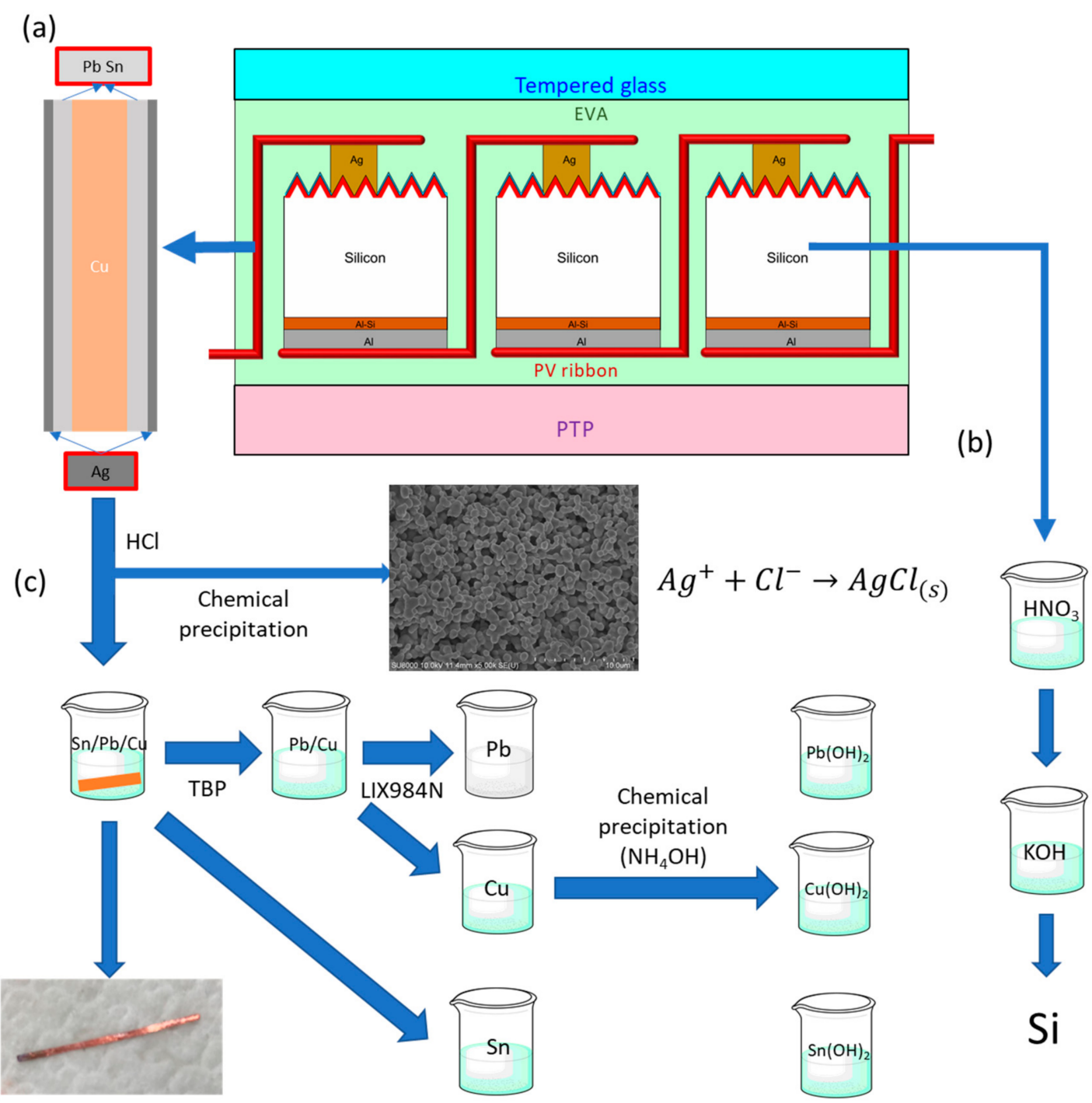

Figure 1. Method for recovering PV cells and PV ribbons. (a) Section views of c-Si PV module and the PV ribbon. (b) Immersing cells in nitric acid and potassium hydroxide for silicon purification. (c) Pretreatment and metal separation of PV ribbon.

\subsection{Pretreatment for Collecting Cells and Ribbons}

In our previous research, $10 \mathrm{~cm} \times 10 \mathrm{~cm}$ PV panel was dismantled to different layers through toluene and thermal treatment [20]. The tempered glass and back sheet were first collected by immersing the panel into $90^{\circ} \mathrm{C}$ toluene for an hour. That swelled the EVA resin between cells and the glass, which let the glass easy to strip of the panel. The sample after removing the tempered glass was heated at $500^{\circ} \mathrm{C}$ at a rate of $10^{\circ} \mathrm{C} / \mathrm{min}$ in an anoxic chamber to eliminate the EVA sheet on the wafer and the rear EVA layer between cells and the back sheet. The wafer was broken during these methods but let us collect ribbon easily. After organic and thermal processes, the tempered glass was collected. Finally, the remaining PV cells and PV ribbons were also collected separately.

\subsection{Methods for Purifying Silicon from the Solar Cells}

PV cells were immersed in nitric acid and potassium hydroxide continuously as shown Figure 1b. Cells after this method were washed $30 \mathrm{~min} 3$ times by the deionized water. Optimal parameters including the concentration of leaching reagent, liquid-solid ratio, reaction time, and reaction temperature were concerned in both reagent systems. The characteristic analysis of silicon resource after purification was also investigated by 
inductively coupled plasma optical emission spectrometry (ICP-OES) and high-resolution scanning electron microscope (HR-SEM, XL30, FEI Ltd., Hillsboro, OR, USA).

\subsection{PV Ribbon Pretreatment and Metal Separation Method}

Figure $1 \mathrm{c}$ shows the method for recovering PV ribbons. This study provided three methods to separate the coating layer from ribbons and ionized metals for the metal separation process. Hydrochloric acid was employed to leach PV ribbon. Ag was separated from other metals by halogenating to $\mathrm{AgCl}$ and the $\mathrm{AgCl}$ was immersed by nitric acid for purifying. To optimize the experimental condition for effective leaching, this study was made carrying different process parameters viz. time $(0.5-4 \mathrm{~h})$, temperature $\left(25-85^{\circ} \mathrm{C}\right)$, liquid-solid ratio, and acid concentration (0.5-6 M).

The leaching efficiency of metal was calculated by the equation below:

$$
X \%=\left(\frac{V_{c} C_{x}}{M W_{x}}\right) \times 100 \% .
$$

$X \%$ leaching efficiency, $M=$ the weight of the sample $(\mathrm{g}), V c=$ the volume of the $\operatorname{liquid}(\mathrm{L}), W x=$ target metals weight fraction $(\mathrm{wt} \%)$.

According to the structure, this section polished the coating $\mathrm{Pb}-\mathrm{Sn}$ layer from copper wire in chemically and physically way individually, then compare the effect. Thermogravimetry Analysis. Differential Thermal Analysis (TG/DTA, NETZSCH-409PC, Linseis, Selb, Germany) was employed to evaluate the oxidation point of the PV ribbon to oxidize the coating layer for polishing.

After pretreatment, metals including $\mathrm{Cu}, \mathrm{Pb}$, and $\mathrm{Sn}$ were ionized into liquid. In this study, both TBP and LIX984N were diluted into kerosene and used as the extractant to separate $\mathrm{Cu}, \mathrm{Pb}$, and $\mathrm{Sn}$. The extraction process was divided into two steps. The first step of extraction was operated by TBP to extract $\mathrm{Sn}$ from liquid and strip it with nitric acid. The extraction efficiency of TBP is mainly controlled by the concentration of coordination complex of $\mathrm{Sn}$ and $\mathrm{Cl}$ ions which means that the high concentration of $\mathrm{H}^{+}$has less effect in this extractant. Thus, this step can nearly not control the $\mathrm{pH}$ value of the leaching reagent to get the best efficiency because the reagent containing concentrated $\mathrm{Cl}^{-}$already. The second step of extraction was operated by LIX984N to extract $\mathrm{Cu}$ from liquid and strip it with sulfuric acid. LIX984N is a chelated extractant. The extraction efficiency of LIX984N is mainly controlled by the affinity between $\mathrm{Cu}$ ion and the extractant. Thus, the chelated extractant such as LIX984N always shows good extraction efficiency on some specific ions. The optimal parameters of extraction including $\mathrm{pH}$ value (adjusted by hydrochloric acid and ammonia), concentration of extractant, aqueous-oil ratio, reaction time and the optimal parameters of stripping including reagent concentration, oil-aqueous ratio, reaction time were investigated. After metal separation methods, metal oxides can be received through concentration and calcination. Silver can be received through concentration and reduction. The final products were $\mathrm{CuO}, \mathrm{PbO}, \mathrm{SnO}_{2}$, and $\mathrm{Ag}$. The purity and composition crystal phase of the product would be investigated also. Ion concentrations in this study were investigated by ICP-OES.

\section{Results}

Figure 2 shows the SEM-EDS figure and the component of PV cells. Most of the impurities of PV cells are on the surface. To recycled high purity of silicon from the waste solar module, the properties of the recycled wafer should be nearly identical to the new one. The metal coating was removed by two-step leaching process. Figure 3 shows the optimized parameters of first step leaching. The first step leaching employed $5 \mathrm{M}$ nitric acid in liquid-solid ratio $25 \mathrm{~mL} / \mathrm{g}$, and reaction timed an hour with reaction temperature $80{ }^{\circ} \mathrm{C}$. In the first step leaching, $99.4 \%$ of $\mathrm{Ag}$ and $76 \%$ of $\mathrm{Al}$ were removed from the cell. $\mathrm{Al}-\mathrm{Si}$ compounds on the back side of cells required the second step leaching to remove. 


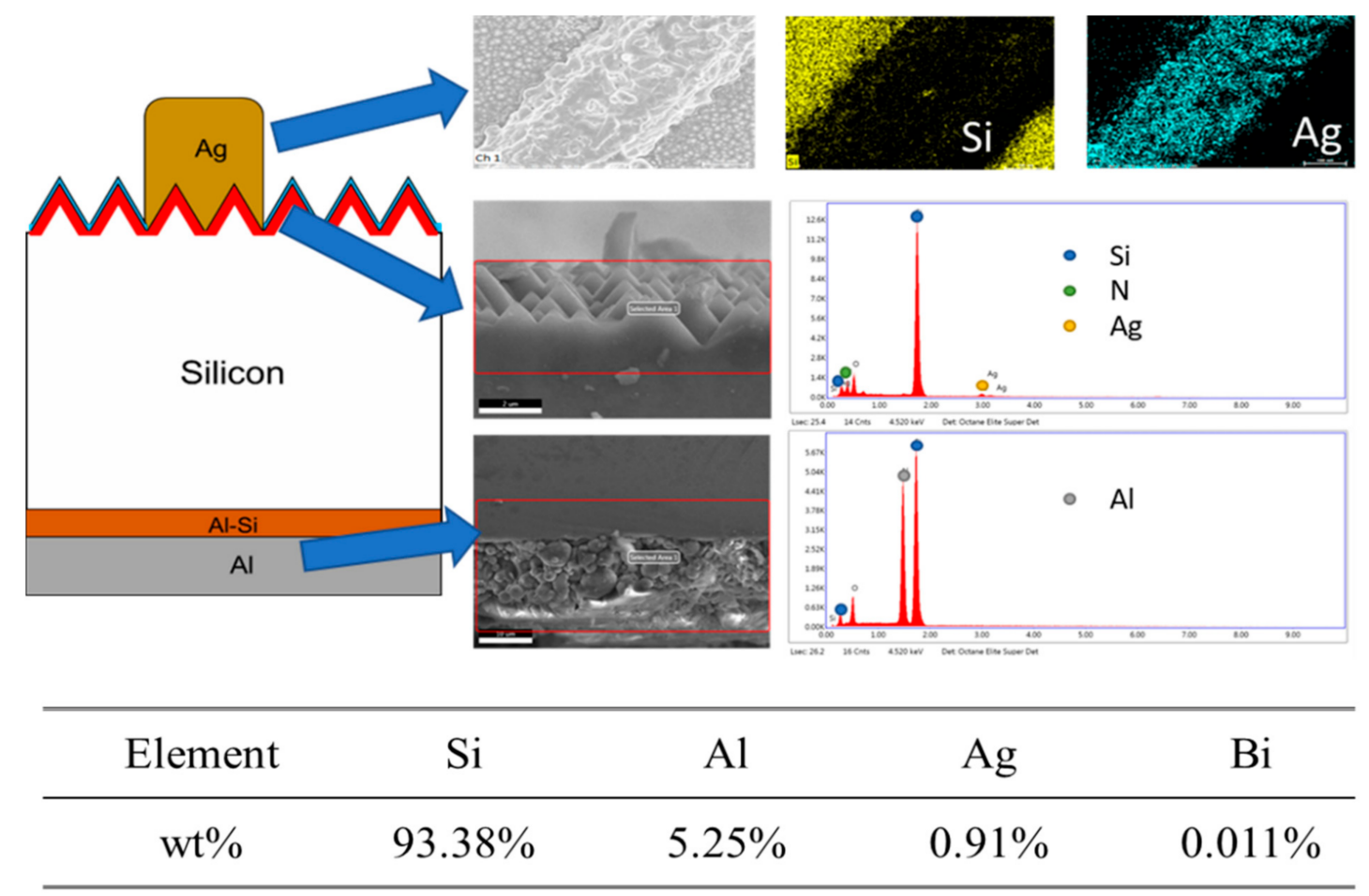

Figure 2. SEM-EDS figure and component of PV cells.
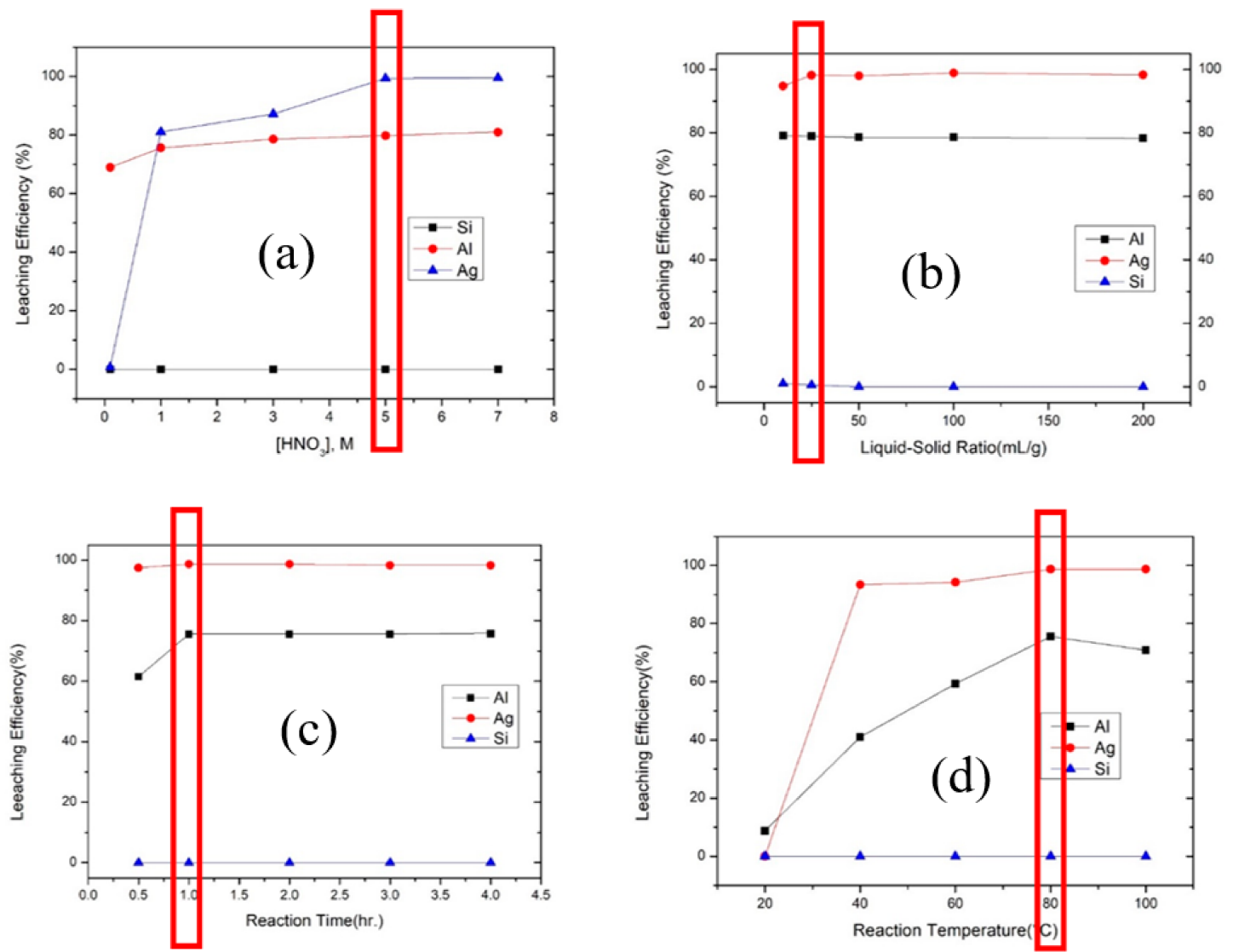

Figure 3. The optimized parameters of first step leaching $\left(\mathrm{HNO}_{3}\right)$ : (a) Concentration of nitric acid, (b) liquid-solid ratio, (c) reaction time, and $(\mathbf{d})$ reaction temperature. 


\subsection{PV Cells Purification by Removing the Metal Coating Layer}

Figure 2 shows the SEM-EDS figure and the component of PV cells. Most of the impurities of PV cells are on the surface. To recycled high purity of silicon from the waste solar module, the properties of the recycled wafer should be nearly identical to the new one. The metal coating was removed by two-step leaching process. Figure 3 shows the optimized parameters of first step leaching. The first step leaching employed $5 \mathrm{M}$ nitric acid in liquid-solid ratio $25 \mathrm{~mL} / \mathrm{g}$, and reaction timed an hour with reaction temperature $80{ }^{\circ} \mathrm{C}$. In the first step leaching, $99.4 \%$ of $\mathrm{Ag}$ and $76 \%$ of $\mathrm{Al}$ were removed from the cell. $\mathrm{Al}-\mathrm{Si}$ compounds on the back side of cells required the second step of leaching to remove.

Figure 4 shows the optimal parameters of second step leaching. The second step leaching employed $1 \mathrm{M} \mathrm{KOH}$ in liquid-solid ratio $50 \mathrm{~mL}$, reaction times an hour, reaction temperature $80^{\circ} \mathrm{C}$. The concentration of metal impurity in silicon purification process is shown in Table 2. Figure 5 shows the SEM-EDS diagram of PV cells after the treatment. These two steps of chemical leaching could produce nearly $3 \mathrm{~N} \mathrm{Si}(99.84 \%)$, and the recovery rate of $\mathrm{Si}$ was $99.9 \%$. Most of the metal components, silicon nitride, and aluminum print electrodes were removed from the cell. However, $1 \mathrm{M} \mathrm{KOH}$ infiltrated $0.03 \%$ of $\mathrm{K}$ in silicon, which caused the impurity issue. Comparing with other research etching by HF [10,11], this research takes more reaction time than the treatment with hydrogen fluoride (HF). However, the application of nitric acid and $\mathrm{KOH}$ treatment still obtained near to $99.9 \%$ of silicon which is closed to the treatment with HF.
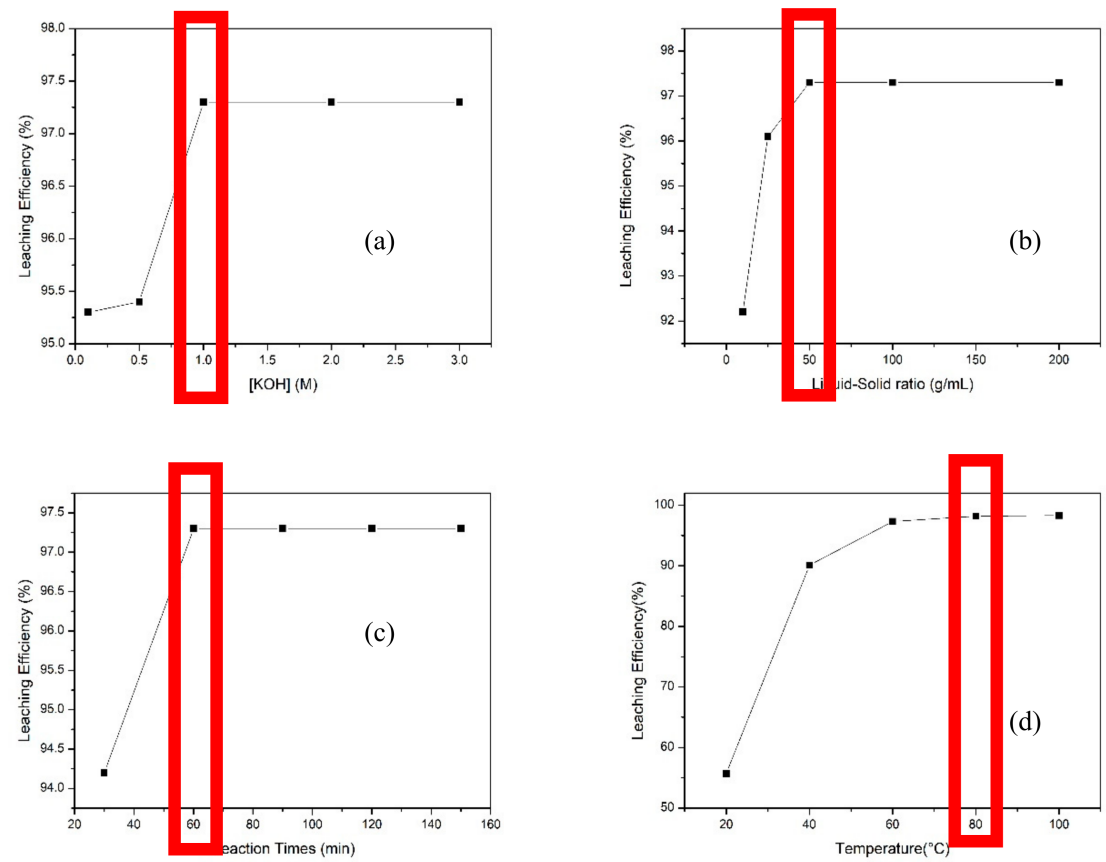

Figure 4. The optimized parameters of second step leaching $(\mathrm{KOH})$ : (a) Concentration of Hydrochloric acid, (b) liquid-solid ratio, (c) reaction time, and (d) reaction temperature.

Table 2. The concentration of metal impurity in silicon purification process.

\begin{tabular}{cccc}
\hline Element & PV Cell $(\mathbf{p p m})$ & 1st Leaching & 2nd Leaching \\
\hline $\mathrm{Al}$ & 567.5 & 189.85 & 12.82 \\
$\mathrm{Ca}$ & 0.7925 & 0.45 & 0.19 \\
$\mathrm{Zn}$ & 0.907 & $\mathrm{~N} . \mathrm{D}$. & N.D. \\
$\mathrm{Fe}$ & 0.344 & 0.03 & 0.07 \\
$\mathrm{Ag}$ & 98.37 & 0.59 & 0.1 \\
$\mathrm{Bi}$ & 1.0795 & N.D. & N.D. \\
$\mathrm{K}$ & N.D. & N.D. & 2.97 \\
\hline Si(purity\%) & $93.38 \%$ & $98.8 \%$ & $99.84 \%$ \\
\hline
\end{tabular}



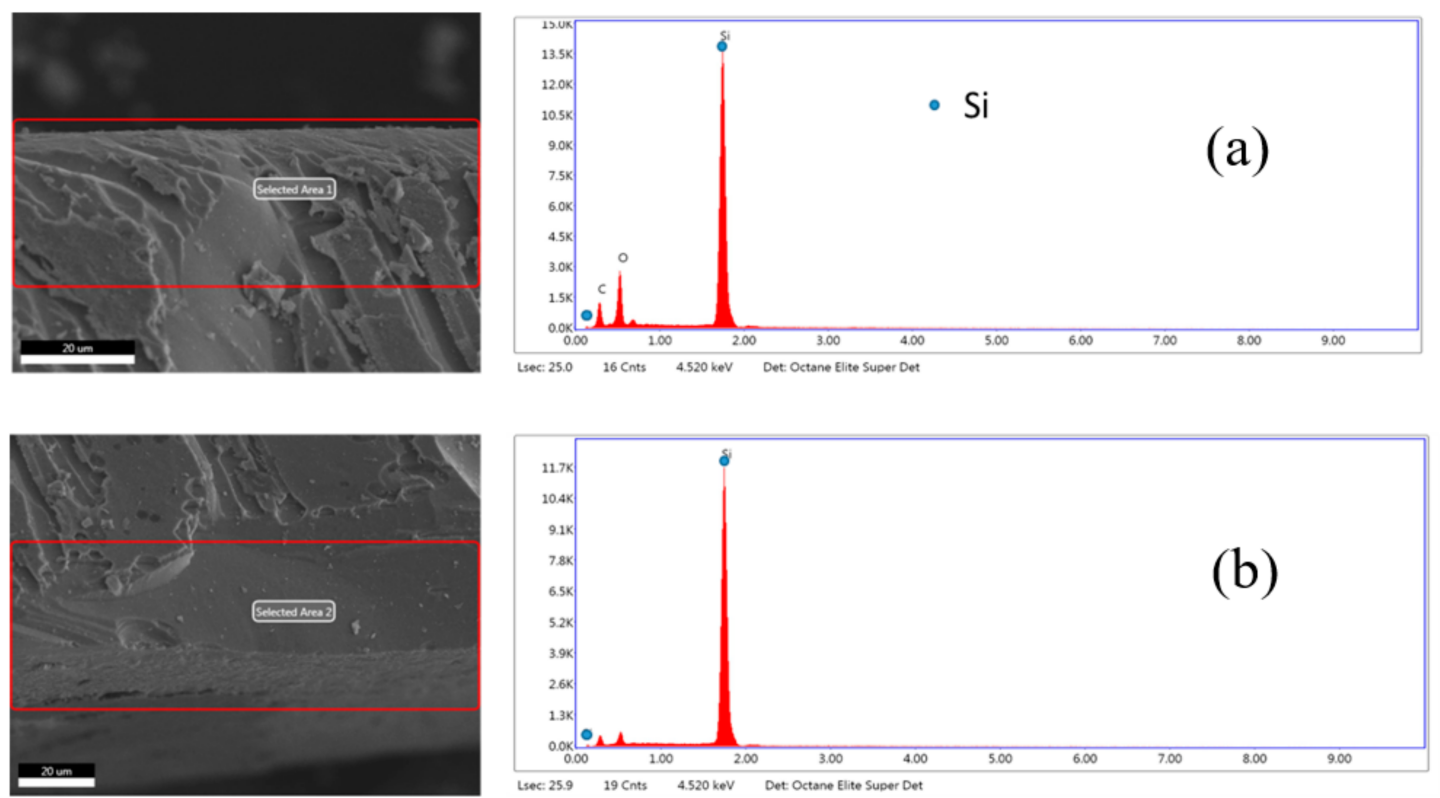

Figure 5. The SEM-EDS diagram of PV cells after purification. (a) Upon of the cell, the structures of antireflection layer, texturization were removed. (b) Back side of the cell, the structure of Al electrode was removed.

\subsection{Metal Separation and Purification of the PV Ribbon}

\subsubsection{Pretreatment of PV Ribbon Separation by Leaching}

Figure 6 shows the SEM-EDS diagram and component of the PV ribbon. According to the structure of the ribbon, $\mathrm{Pb}-\mathrm{Sn}$ alloy, and $\mathrm{Ag}$ coated copper wire surface, this research operated two ways including leaching the ribbon then operating metal separation or removing the coating layer then collected copper wire. Figure 7 shows the optimized parameters of leaching the PV ribbon. Three moles of hydrochloric acid with $6 \%$ of $\mathrm{H}_{2} \mathrm{O}_{2}$ could initially separate $\mathrm{Ag}$ from other metals in liquid-solid ratio 50 with reaction times $60{ }^{\circ} \mathrm{C}$ and reaction temperature $60^{\circ} \mathrm{C}$. The leaching efficiencies of leaching PV ribbons were $99.65 \%$ of $\mathrm{Cu}, 98.3 \%$ of $\mathrm{Pb}, 99 \%$ of $\mathrm{Sn}$, and $0 \%$ of $\mathrm{Ag}$.

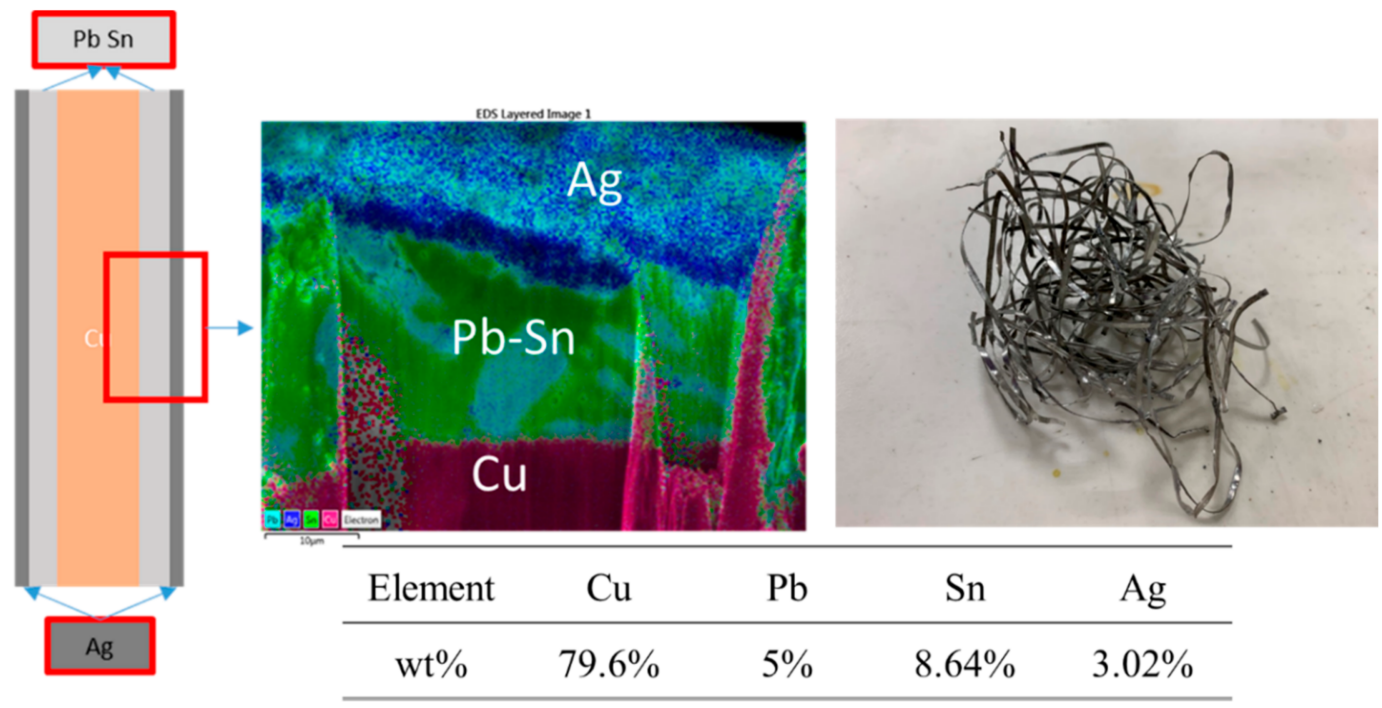

Figure 6. The SEM diagram and component of the PV ribbon. 

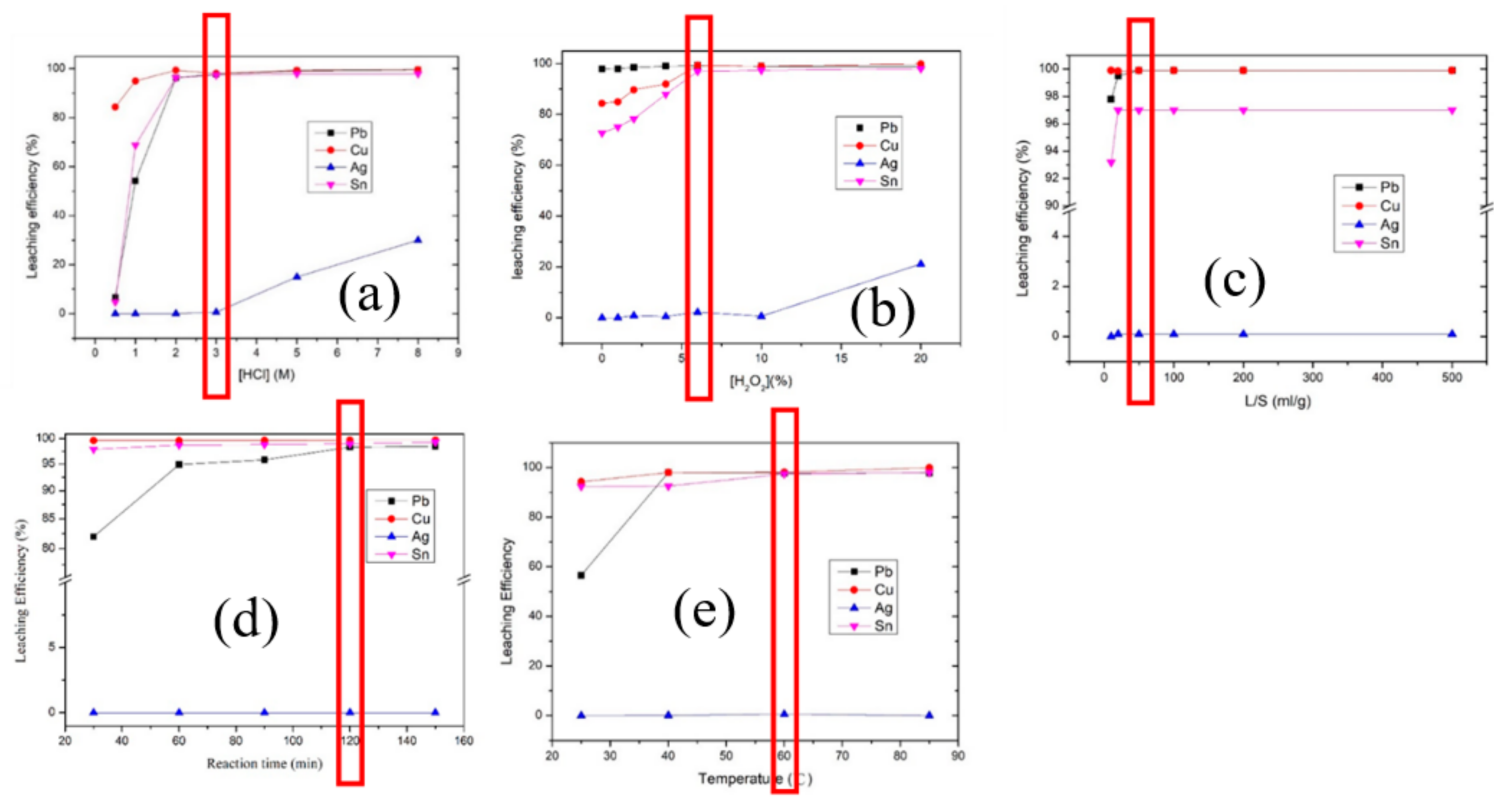

Figure 7. The optimized parameters of PV ribbon leaching treatment: (a) Concentration of Hydrochloric acid, (b) concentration of $\mathrm{H}_{2} \mathrm{O}_{2}$, (c) liquid-solid ratio. (d) Reaction time, and (e) reaction temperature.

\subsubsection{Pretreatment of PV Ribbon Metal Separation by Removing Coating Layer}

The method to collect copper wires can be classified according to the separation method including chemical and physical ways. The chemically way was an extension of the former leaching treatment. The same leaching reagent was employed to separate coating layers from the ribbon by optimizing reaction times. 90s reaction time shown in Figure 8 a was chosen because of the selectivity of copper (leaching efficiency $80.8 \%$ of $\mathrm{Pb}$, $99.3 \%$ of $\mathrm{Sn}$, and $10 \%$ of $\mathrm{Cu}$ ). Based on Sang Hyeon Choi's research [21], $\mathrm{Pb}$ (II) ion generally relies on the precipitation of $\mathrm{PbCl}_{2}$ in diluted $\mathrm{Cl}^{-}$solvent. However, concentrated $\mathrm{Cl}$ ion in oxidation condition can effectively increase the leaching ability of $\mathrm{Pb}$. To remove more lead from the ribbon, the concentration of $\mathrm{Cl}^{-}$was also optimized by adding $\mathrm{NaCl}$. The result

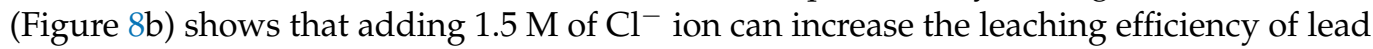
from $80.2 \%$ to $99.9 \%$. The purity of $99.56 \%$ of copper wire was obtained after the chemically treatment.

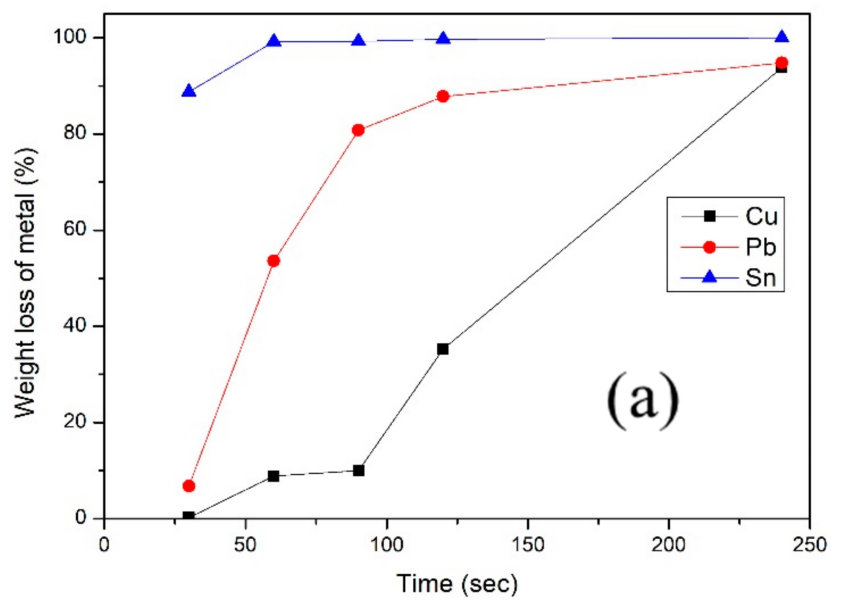

(a)

Figure 8. Cont. 


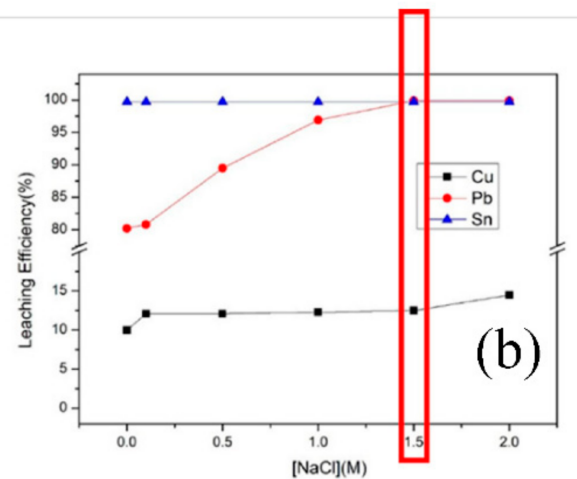

(b)

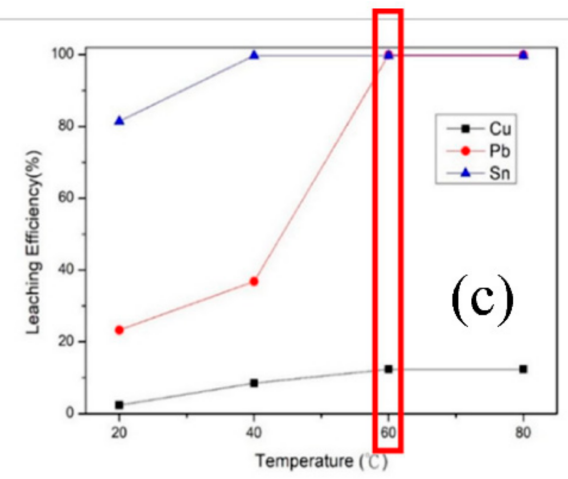

(c)

Figure 8. The optimized parameters of removing PV ribbon's coating layer: (a) Optimizing reaction times, (b) concentration of $\mathrm{NaCl}(\mathrm{M})$, and (c) reaction temperature.

The physically way for removing coating layer was operated by using oxidation method to oxidize the coating layer and polish the layer from ribbon. The oxidation of PV ribbon has been conducted in $1 \mathrm{~atm}$ air at different temperatures from $20^{\circ} \mathrm{C}$ to $1000{ }^{\circ} \mathrm{C}$ using thermogravimetric and differential thermal analysis (TG/DTA) to find suitable temperatures at which the coating layer totally was oxidized. There are two obviously weight change on $600{ }^{\circ} \mathrm{C}$ and $830^{\circ} \mathrm{C}$ shown on TG/DTA figure of PV ribbon (Figure 9). The first peak of weight changing suggested that the coating layer started to oxidize, and the second peak referred the oxidation of copper wire started to oxidize. In this case, this study set the oxidation method parameter as $800^{\circ} \mathrm{C}$ to oxidize the coating layer. After oxidation, the ribbon was polished. Twenty-seven percent of weight was polished and the purity of copper wire was $99.63 \%$ in the end. Table 3 shows the purities and the component of two coating layer removing method. The physical separation method obtained $99.63 \%$ of copper wire that was better than optimizing reaction time. Moreover, the physical treatment cost less than the chemical treatment. Comparing two ways to remove coating layer, optimizing reaction times has less purity than the physical separation because of sodium infiltrating. However, comparing with the physical separation, optimizing reaction times shows more potential to removing metallic component.

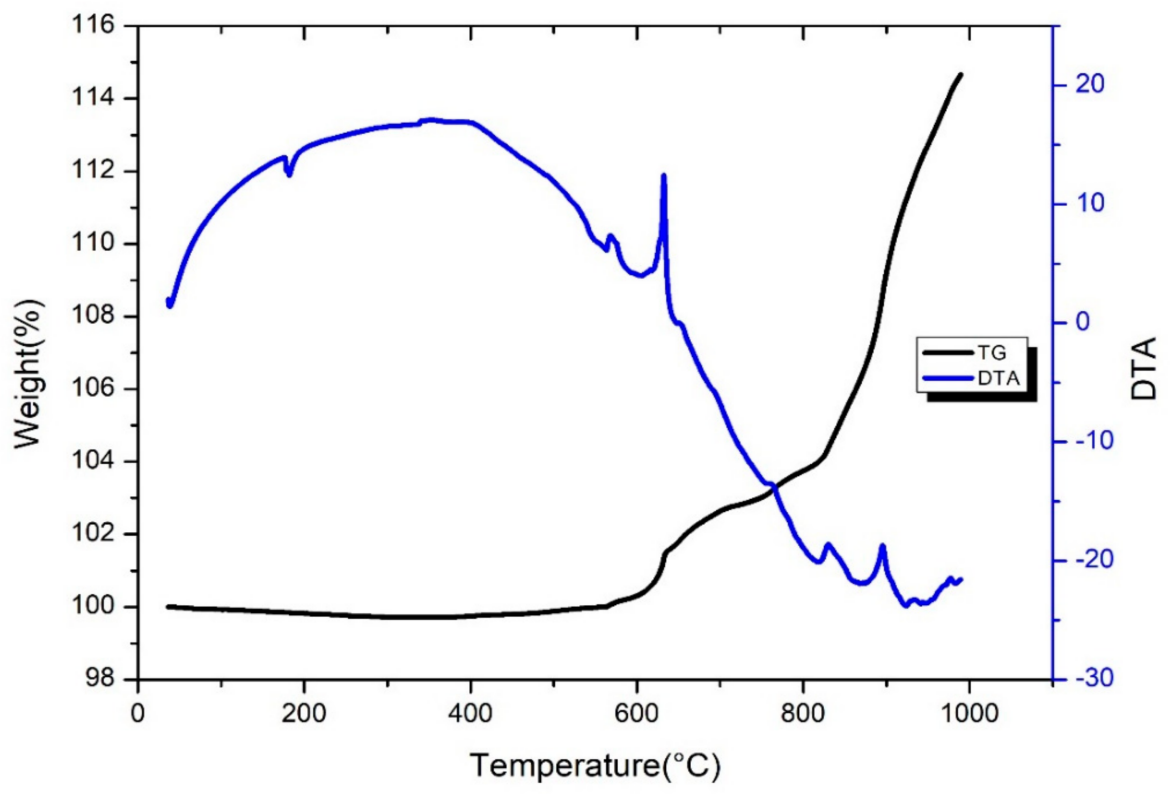

Figure 9. TG/DTA of PV ribbon $\left(25-1000^{\circ} \mathrm{C}, 10 \mathrm{~K} / \mathrm{min}\right.$, Air). 
Table 3. The component of copper wire after two coating layers removing methods.

\begin{tabular}{ccc}
\hline \multirow{2}{*}{ Element } & \multicolumn{2}{c}{ Cu Wire Purity } \\
\cline { 2 - 3 } & Chemical Separation & Physical Separation \\
\hline $\mathrm{Pb}$ & $0.05 \%$ & $0.1 \%$ \\
$\mathrm{Sn}$ & $0.15 \%$ & $0.27 \%$ \\
$\mathrm{Ag}$ & $\mathrm{N} . \mathrm{D}$. & N.D. \\
$\mathrm{Na}$ & $0.23 \%$ & N.D. \\
\hline $\mathrm{Cu}($ purity $\%)$ & $99.57 \%$ & $99.63 \%$ \\
\hline
\end{tabular}

\subsubsection{Extraction of Leaching Solution after PV Ribbon Pretreatment}

After the pretreatment, this research ionized $\mathrm{Cu}, \mathrm{Sn}$, and $\mathrm{Pb}$ in the leaching solution. To separate metals individually, two steps of extraction process including TBP system and LIX984N system were employed. The extraction efficiency is described as

$$
\text { extraction ef ficiency }=\left(1-\frac{\text { concentration after extraction }}{\text { concentration before extraction }}\right) \times 100 \% \text {. }
$$

The reaction equation of both extractant is described as

$$
\begin{gathered}
\mathrm{SnCl}_{4}\left(\mathrm{H}_{2} \mathrm{O}\right)_{5(a q)}+n \mathrm{TBP} P_{\text {org }} \rightarrow \mathrm{SnCl}_{4}\left(\mathrm{H}_{2} \mathrm{O}\right)_{5-n} \mathrm{TBP} P_{n(\text { org })}+n \mathrm{H}_{2} \mathrm{O} \\
\mathrm{Cu}_{(a q)}^{2+}+2 \mathrm{HA}_{(\text {org })} \rightarrow \mathrm{CuA}_{2, \mathrm{o}}+2 \mathrm{H}_{(a q)}^{+} .
\end{gathered}
$$

As the equation showing upon, the Sn extraction efficiency is controlled by the properties of the tetrachloro complex and TBP. Moreover, the leaching solution in this research contained concentrated $\mathrm{Cl}^{-}$ions which is easy to produce the environment for Sn to transfer to tetrachloro complex. Figure 10a reveals the high efficiency of TBP extracting tin from liquid in concentrated acid solution. That indicated the feasibility to separate tin via the concentration of hydrochloride acid. In addition, the extraction efficiency affected by different extractant concentration, aqueous-organic ratio, and reaction time was also investigated. Figure $10 \mathrm{~b}$ shows that $30 \%$ of TBP is appropriate to extract tin from the solution. Figure 10c shows the extraction efficiency by optimizing the aqueous-organic ratio. Aqueous-oil ratio (A / O) 0.5 shows the best extraction parameter (99.9\%). However, the high separation factor of $\mathrm{Sn} / \mathrm{Cu}$ (315.53) and $\mathrm{Sn} / \mathrm{Pb}(9570.1)$ indicated that $\mathrm{A} / \mathrm{O}$ ratio 10 can concentrate more tin but less copper and lead coextract than A/O 0.5 can. However, there was only $86.22 \%$ leaching efficiency at A/O 10. The extraction efficiencies of tin extraction were $\mathrm{Sn} 86.22 \%, \mathrm{~Pb} 0.6 \%$, and $\mathrm{Cu} 2 \%$. To increase the recovery rate of tin, this study operated a McCable-Thiele Diagram for multi-stage extraction research. Figure 10e shows that after three stages of extraction, the efficiency should be $99.9 \%$. This research set three-stage extraction as the optimal parameter.
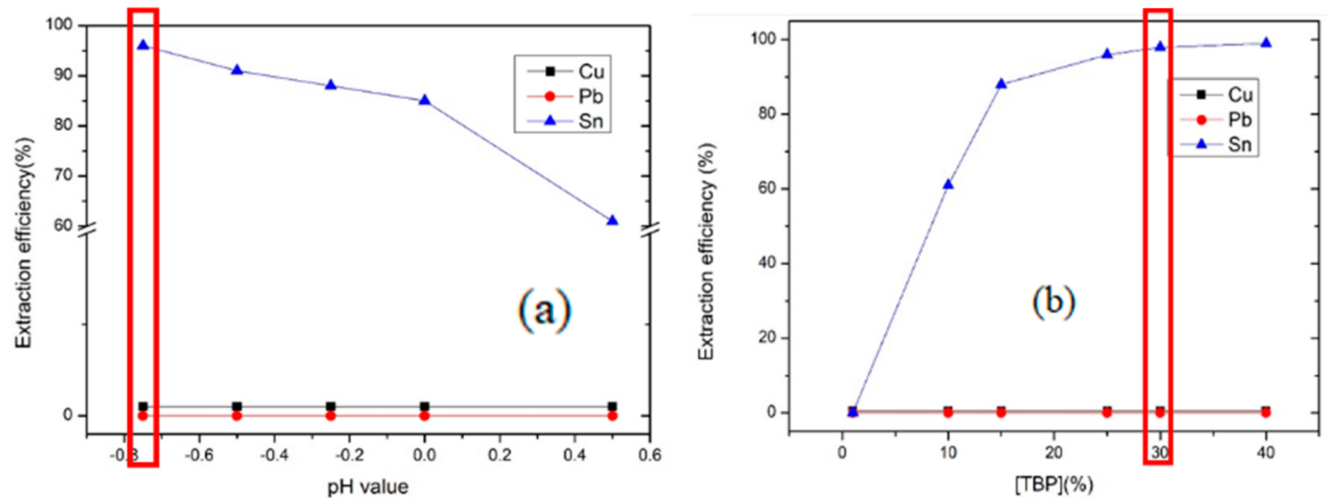

Figure 10. Cont. 

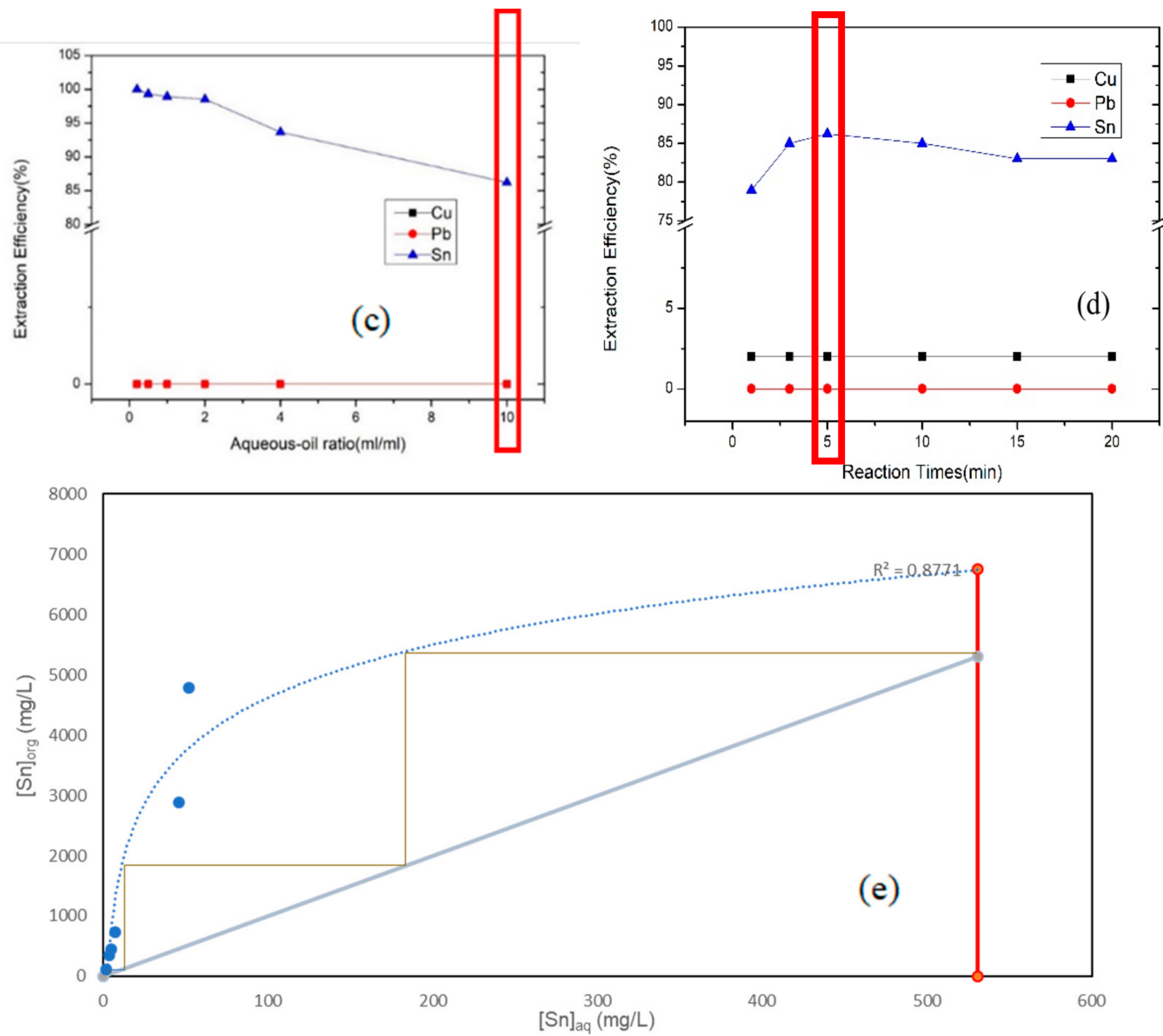

Figure 10. Effect of tin extraction efficiency on (a) $\mathrm{pH}$ value, (b) concentration of TBP, (c) A/O ratio, and (d) reaction times. (e) McCable-Thiele Diagram for stimulating the stage of extraction in AO ratio 10.

After TBP extraction, the leaching solution remained $\mathrm{Pb}$ and $\mathrm{Cu}$ for the following method. LIX984N was employed to extract $\mathrm{Cu}$ from the liquid. Although the extraction efficiency of LIX984N is mainly controlled by the affinity between $\mathrm{Cu}$ ion and the extractant. The hydroxyl group from the extractant release $\mathrm{H}+$ to balance the voltage. As the equation shown upon, it demonstrates that the feasibility to separate copper via the $\mathrm{H}+$ controlling. Figure 11a reveals the high efficiency of copper at $\mathrm{pH}=1$ but also extracted $30 \%$ of $\mathrm{Pb}$ simultaneously. This situation was concerned with the over addition of extractant. Figure $11 \mathrm{~b}$ shows that if the extractant concentration declined to $5 \%$, the problem of coextraction would be solved. Therefore, this research set $5 \%$ of extractant as the optimal parameters. The optimal parameter of $\mathrm{A} / \mathrm{O}$ ratio was set as 1 because the efficiency declined after increasing the A / O to more than 2. LIX984N is an effective extractant for copper. Figure 11d shows that the reaction time of extracting copper only take $30 \mathrm{~s}$ to complete. This research set reaction time $30 \mathrm{~s}$ as the optimal parameter. Table 4 shows the optimal parameters of both extraction processes.

Table 4. Optimal parameters of extraction process.

\begin{tabular}{ccccc}
\hline & pH Value & $\begin{array}{c}\text { Concentration of } \\
\text { Extractant (\%) }\end{array}$ & A/O Ratio & Reaction Time (min) \\
\hline Tin & -0.75 & $30 \%$ & $10: 1$ & 5 \\
Copper & 1 & $5 \%$ & $1: 1$ & 0.5 \\
\hline
\end{tabular}



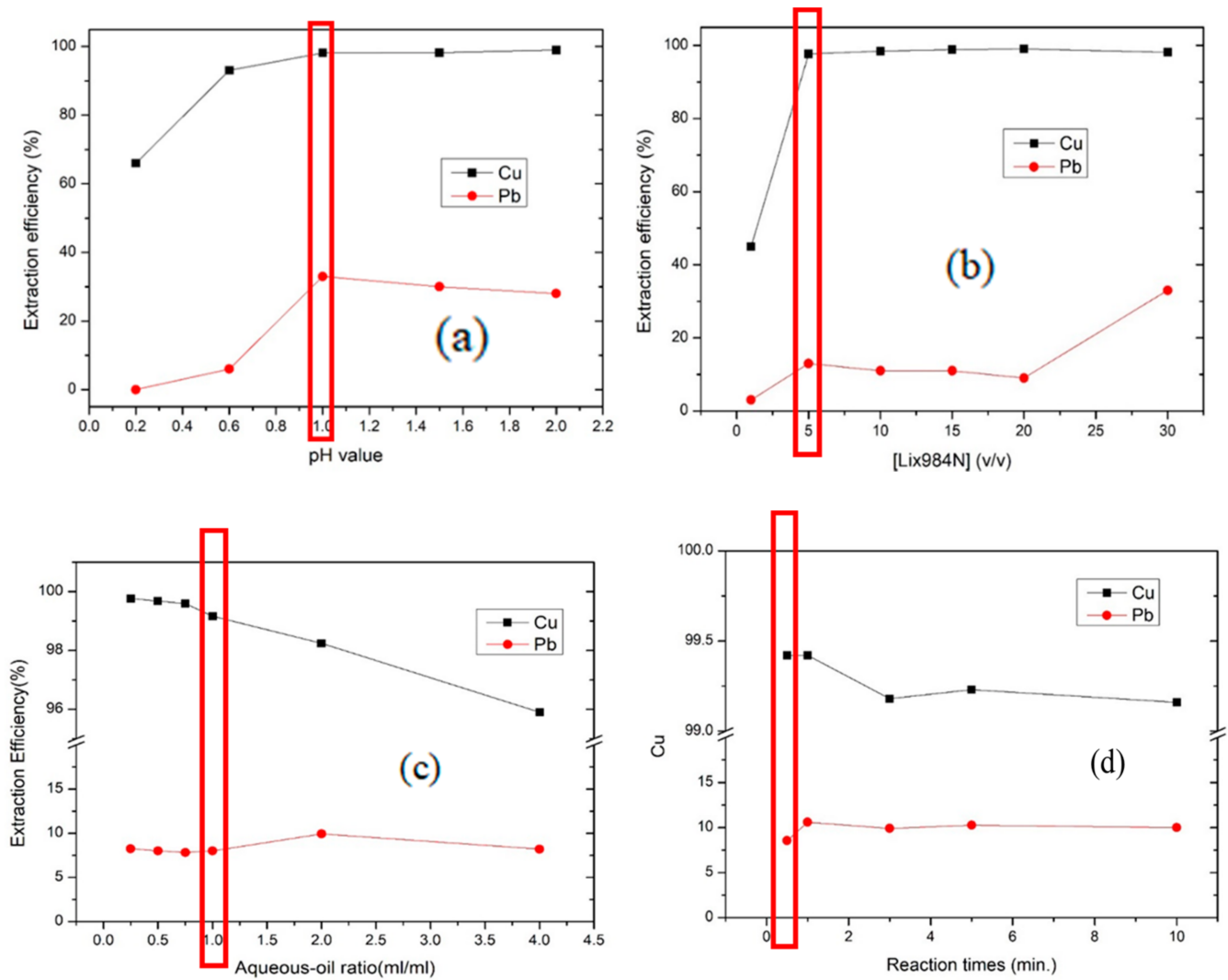

Figure 11. Effect of copper and lead extraction efficiency on (a) pH value, (b) LIX984N concentration, (c) $\mathrm{A} / \mathrm{O}$ ratio, $(\mathrm{d})$ reaction time.

After the solvent extraction, the separated copper and tin in organic phase continued the stripping process for chemical precipitation in aqueous phase. Table 5 shows the optimal parameter of both extractants. One mole of nitric acid and three moles of sulfuric acid were employed to strip tin and copper from the organic phase. The stripping efficiency was determined by the metal concentration related to extraction and after stripping analyzed by ICP-OES as

stripping efficiency $=\left(\frac{\text { concentration after stripping }}{\text { concentration before extraction }- \text { concentration after extraction }}\right) \times 100 \%$.

Table 5. Optimal parameters of stripping process.

\begin{tabular}{cccccc}
\hline & \multicolumn{2}{c}{$\begin{array}{c}\text { Concentration of Stripping } \\
\text { Liquid }\end{array}$} & O/A & $\begin{array}{c}\text { Reaction Time } \\
\text { (min) }\end{array}$ & Efficiency \\
\hline Tin & $\mathrm{HNO}_{3}$ & $1 \mathrm{M}$ & 1 & 10 & $97.3 \%$ \\
Copper & $\mathrm{H}_{2} \mathrm{SO}_{4}$ & $3 \mathrm{M}$ & 1 & 10 & $99.4 \%$ \\
\hline
\end{tabular}

\subsection{Characteristic Analysis of the Product}

\subsubsection{Analysis of Silver}

The Ag residue after PV ribbon pretreatment was leached by $5 \mathrm{M}$ nitric acid from PV cell purification. $\mathrm{Ag}^{+}$ion was precipitated by sodium chloride to separate with aluminum ion in $\mathrm{AgCl}$ state. Sodium hydroxide was employed to transfer $\mathrm{AgCl}$ to silver oxide $\left(\mathrm{Ag}_{2} \mathrm{O}\right)$ and silver oxide was reduced by dextrose. The purity and recovery rate of Ag are $98.85 \%$ and $99.7 \%$ respectively.

\subsubsection{Characteristic Analysis of $\mathrm{CuO}, \mathrm{SnO}_{2}$, and $\mathrm{PbO}$}

$\mathrm{Cu}^{2+}, \mathrm{Sn}^{4+}$, and $\mathrm{Pb}^{2+}$ ions after metal separation process via extraction and stripping would transfer to copper sulfate, stannic nitrate, and lead perchlorate solution. Ammonia 
was conducted to obtain three metal hydroxides respectively. The residues after precipitation was screened for calcination to obtain the oxide products. The metal hydroxides were analyzed by TGA when the temperature increased from $25-1000{ }^{\circ} \mathrm{C}$. Figure 12 shows the TGA of $\mathrm{Cu}(\mathrm{OH})_{2}, \mathrm{Sn}(\mathrm{OH})_{4}$, and $\mathrm{Pb}(\mathrm{OH})_{2}$. The status reveals that the temperature after $700{ }^{\circ} \mathrm{C}$ can dehydrated these three hydroxides, and the temperature was checked at $700{ }^{\circ} \mathrm{C}$ for $\mathrm{Cu}(\mathrm{OH})_{2}, 400{ }^{\circ} \mathrm{C}$ for $\mathrm{Sn}(\mathrm{OH})_{4}$, and $550{ }^{\circ} \mathrm{C}$ for $\mathrm{Pb}(\mathrm{OH})_{2}$ to transform into metal oxides. X-ray diffraction (XRD, Haoyuan DX-2000) and ICP-OES were employed to analyze characterization and purity of the final products. The XRD diagrams make sure that the products were $\mathrm{CuO}, \mathrm{SnO}_{2}$, and $\mathrm{PbO}$ as shown in Figure 13. The products were dissolved in aqua regia to survey the impurities using ICP-OES. The mass fraction of impurities in the products are shown in Table 6, and the purities of copper, tin, and lead are 99.7\%, 99.47\%, and $99.68 \%$ respectively. Moreover, the recovery rate of copper, tin, and lead are $98.5 \%$, $96.5 \%$, and $88.9 \%$ respectively.

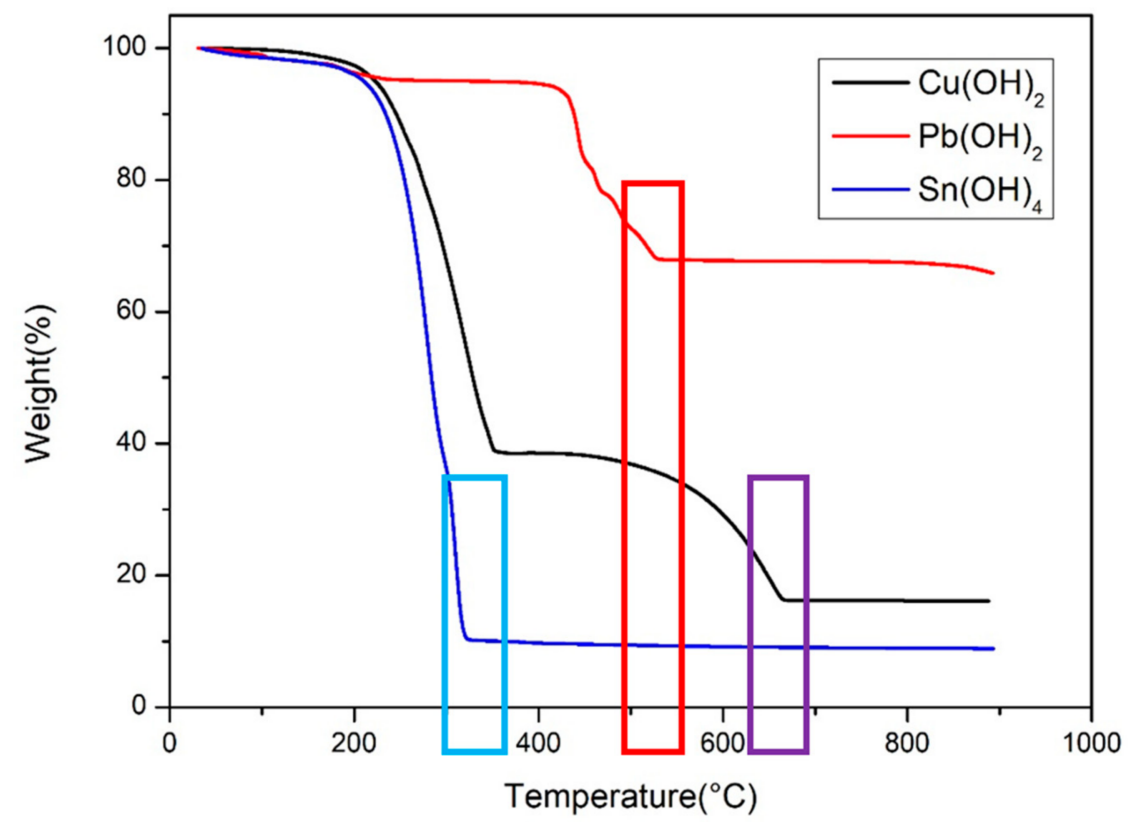

Figure 12. TGA analysis of the metal hydroxides.

Table 6. Mass fraction of impurities in the products.

\begin{tabular}{cccccc}
\hline Compound & $\mathbf{C u O}$ & $\mathbf{P b O}$ & $\mathbf{S n O}_{2}$ & Compound & Ag \\
\hline $\mathrm{CuO}$ & $99.7 \%$ & $0.152 \%$ & $0.11 \%$ & $\mathrm{Cu}$ & $0.95 \%$ \\
$\mathrm{PbO}$ & N.D. & $99.47 \%$ & $0.04 \%$ & $\mathrm{~Pb}$ & $0.11 \%$ \\
$\mathrm{SnO}$ & N.D. & N.D & $99.68 \%$ & $\mathrm{Sn}$ & N.D. \\
$\mathrm{Ag}_{2} \mathrm{O}$ & N.D. & $0.09 \%$ & N.D. & $\mathrm{Ag}$ & $98.85 \%$ \\
$\mathrm{Al}_{2} \mathrm{O}_{3}$ & $0.09 \%$ & $0.171 \%$ & $0.11 \%$ & $\mathrm{Al}$ & $0.05 \%$ \\
$\mathrm{Na}_{2} \mathrm{O}$ & $0.18 \%$ & $0.098 \%$ & $0.06 \%$ & $\mathrm{Na}$ & $0.04 \%$ \\
$\mathrm{~K}_{2} \mathrm{O}$ & N.D. & $0.011 \%$ & N.D. & K & N.D. \\
\hline
\end{tabular}



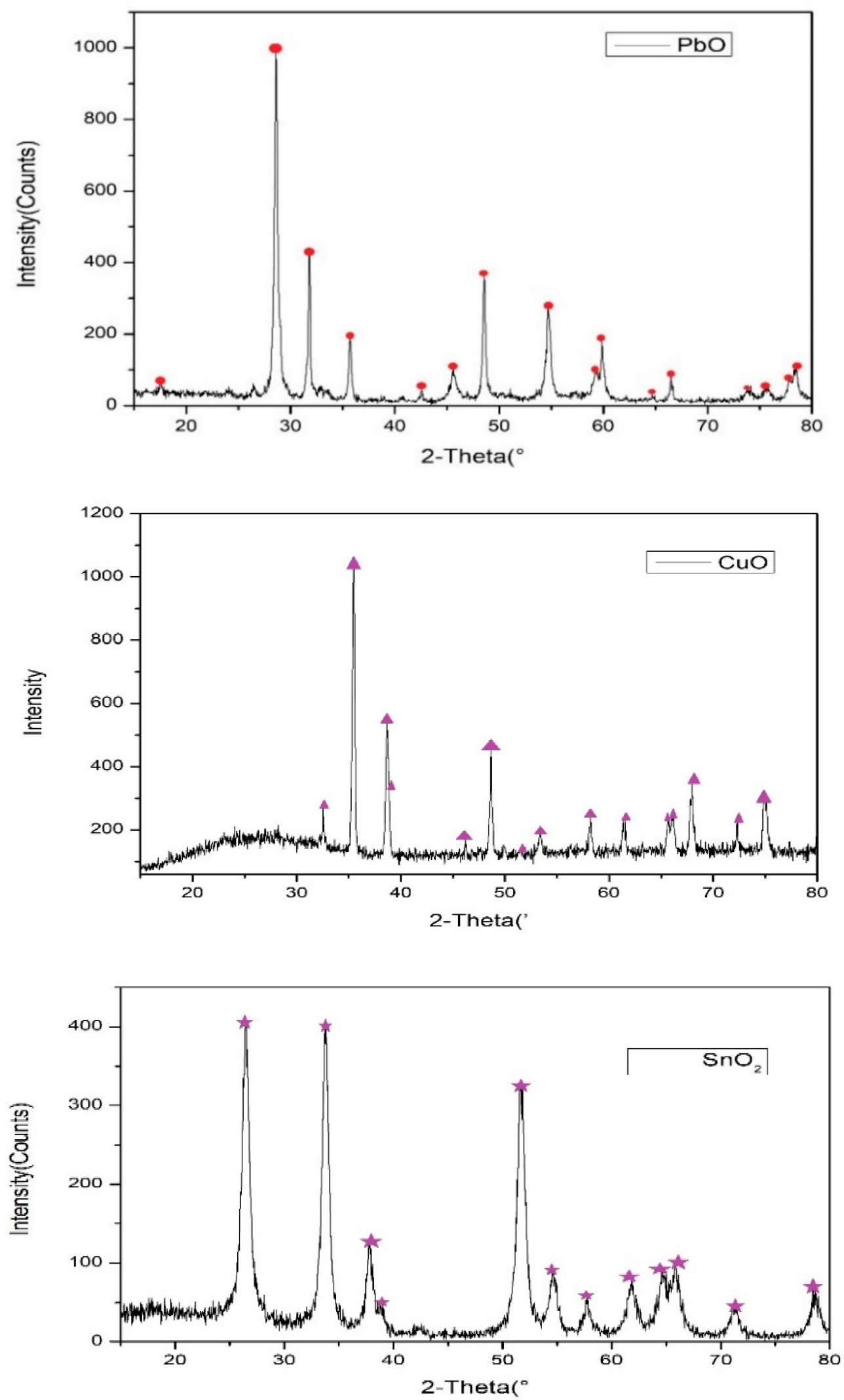

Figure 13. $\mathrm{XRD}$ diagrams of $\mathrm{CuO}, \mathrm{SnO}_{2}$, and $\mathrm{PbO}$.

\section{Conclusions}

1. PV cell contains Si 93.38\%, Al 5.25\%, and Ag 0.91\%. Five moles of nitric acid and one mole of potassium hydroxide were employed to silicon purification two-step leaching. 
$99.7 \%$ of silver and $98.9 \%$ of aluminum were dissolved and separated. The purity of silicon was $99.84 \%$.

2. PV ribbon contains $\mathrm{Cu} 79.6 \%, \mathrm{~Pb} 5 \%$, Sn $8.64 \%$, and $\mathrm{Ag} 3.02 \% .3 \mathrm{M} \mathrm{HCl}$ can initially separate silver from other metals. After optimizing the parameters, chemical polishing can obtain $99.57 \%$ copper wire, and physical polishing can obtain $99.63 \%$.

3. Extraction efficiency of tin was $86.22 \%$ and concentrated 8 times of tin in TBP, and McCabe-Thiele Diagram showed that 3 step extraction can extract $99.9 \%$ of tin. Extraction efficiency of copper was $99.4 \%$ in LIX984N.

4. The purities of final products in this research are $98.85 \%$ of silver, $99.7 \%$ of $\mathrm{CuO}$, $99.47 \%$ of $\mathrm{PbO}$, and $99.68 \%$ of $\mathrm{SnO}_{2}$, and the recovery rates of each are $98.5 \%, 96.5 \%$, and $88.9 \%$ respectively.

5. This study provides the separation and purification of $\mathrm{Si}, \mathrm{Ag}, \mathrm{Cu}, \mathrm{Sn}$, and $\mathrm{Pb}$ from waste PV cell and ribbon for supplying source manufacturers and contributes to recycling end-of-life PV modules.

Author Contributions: Conceptualization, W.-S.C., Y.-L.C., and Y.-J.C. (Yen-Jung Chen); methodology, C.-H.L., Y.-A.C., and Y.-J.C. (Yen-Jung Chen); data curation, Y.-J.C. (Yen-Jung Chen) and Y.-J.C. (Yi-Jin Cheng); investigation, Y.-C.W.; writing—original draft preparation, Y.-J.C. (Yen-Jung Chen); writing-review and editing, Y.-J.C. (Yen-Jung Chen) and. F.-W.L. All authors have read and agreed to the published version of the manuscript.

Funding: This research received no external funding.

Acknowledgments: This work was supported by Laboratory of Resource Circulation in Dept. of Resources Engineering, National Cheng-Kung University.

Conflicts of Interest: The authors declare no conflict of interest.

\section{References}

1. Williams, R. Becquerel Photovoltaic Effect in Binary Compounds. J. Chem. Phys. 1960, 32, 1505-1514. [CrossRef]

2. Fraunhofer Institute for Solar Energy Systems (ISE). Photovoltaic Report. Available online: https://www.ise.fraunhofer.de/ content/dam/ise/de/documents/publications/studies/Photovoltaics-Report.pdf (accessed on 1 April 2021).

3. International Renewable Energy Agency. Renewable Capacity Statistics 2020 International Renewable Energy Agency (IRENA). 2020. Available online: https://irena.org/-/media/Files/IRENA/Agency/Publication/2020/Mar/IRENA_RE_Capacity_ Statistics_2020.pdf (accessed on 1 April 2021).

4. Doi, T.; Tsuda, I.; Unagida, H.; Murata, A.; Sakuta, K.; Kurokawa, K. Experimental study on PV module recycling with or-ganic solvent method. Sol. Energy Mater. Sol. Cells 2001, 67, 397-403. [CrossRef]

5. Klugmann-Radziemska, E.; Ostrowski, P.; Drabczyk, K.; Panek, P.; Szkodo, M. Experimental validation of crystalline silicon solar cells recycling by thermal and chemical methods. Sol. Energy Mater. Sol. Cells 2010, 94, 2275-2282. [CrossRef]

6. Kang, S.; Yoo, S.; Lee, J.; Boo, B.; Ryu, H. Experimental investigations for recycling of silicon and glass from waste photovoltaic modules. Renew. Energy 2012, 47, 152-159. [CrossRef]

7. Lee, J.-K.; Lee, J.-S.; Ahn, Y.-S.; Kang, G.-H.; Song, H.-E.; Kang, M.-G.; Kim, Y.-H.; Cho, C.-H. Simple pretreatment processes for successful reclamation and remanufacturing of crystalline silicon solar cells. Prog. Photovoltaics Res. Appl. 2018, 26, 179-187. [CrossRef]

8. Chang, Y.-W.; Lee, C.-H.; Popuri, S.R.; Hung, C.-E.; Liao, C.-H.; Chang, J.-E.; Chen, W.-S. Recovery of silicon copper and aluminum from scrap silicon wafers by leaching and precip-itation. Environ. Eng. Manag J. 2018, 17, 561-568. [CrossRef]

9. Wang, T.; Hsiao, J.; Du, C. Recycling of materials from silicon vase solar cell module. In Proceedings of the 2012 38th IEEE Photovoltaic Specialists Conference, Austin, TX, USA, 3-8 June 2012.

10. Frisson, L.; Lieten, K.; Bruton, T.; Declercq, K.; Szlufcik, J.; De Moor, H.; Gorts, M.; Benali, A.; Aceves, O. Recent Improvements in Industrial PV Module Recycling. In Proceedings of the 16th European Photovoltaic Solar Energy Conference, Glasgow, UK, 1-5 May 2000.

11. Park, J.; Park, N. Wet etching processes for recycling crystalline silicon solar cells from end-of-life photovoltaic modules. RSC Adv. 2014, 4, 34823-34829. [CrossRef]

12. Jung, B.; Park, J.; Seo, D.; Park, N. Sustainable system for raw-metal recovery from crystalline silicon solar panels: From no-ble-metal extraction to lead removal. ACS Sustain. Chem. Eng. 2016, 4, 4079-4083. [CrossRef]

13. Shin, J.; Park, J.; Park, N. A method to recycle silicon wafer from end-of-life photovoltaic module and solar panels by using recycled silicon wafers. Sol. Energy Mater. Sol. Cells 2017, 162, 1-6. [CrossRef] 
14. Bombach, E.; Röver, I.; Müller, A.; Schlenker, S.; Wambach, K.; Kopecek, R.; Wefringhaus, E. Technical experience during ther-mal and chemical recycling of a 23 year old PV generator formerly installed on pellworm island. In Proceedings of the 21st European Photovoltaic Solar Energy Conference, Dresden, Germany, 4-8 September 2006.

15. Yousef, S.; Tatariants, M.; Denafas, J.; Makarevicius, V.; Lukošiūtè, S.; Kruopienè, J. Sustainable industrial technology for recovery of Al nanocrystals, Si micro-particles and Ag from solar cell wafer production waste. Sol. Energy Mater. Sol. Cells 2019, 191, 493-501. [CrossRef]

16. Yi, Y.K.; Kim, H.S.; Tran, T.; Kil Hong, S.; Kim, M.J. Recovering valuable metals from recycled photovoltaic modules. J. Air Waste Manag. Assoc. 2014, 64, 797-807. [CrossRef] [PubMed]

17. Lee, J.-S.; Ahn, Y.-S.; Kang, G.-H.; Wang, J.-P. Recovery of 4N-grade copper from photovoltaic ribbon in spent solar module. Mater. Technol. 2016, 31, 574-579. [CrossRef]

18. Kim, S.; Lee, J.-C.; Lee, K.-S.; Yoo, K.; Alorro, R.D. Separation of Tin, Silver and Copper from Waste Pb-free Solder Using Hydrochloric Acid Leaching with Hydrogen Peroxide. Mater. Trans. 2014, 55, 1885-1889. [CrossRef]

19. Moon, G.; Yoo, K. Separation of $\mathrm{Cu}, \mathrm{Sn}, \mathrm{Pb}$ from photovoltaic ribbon by hydrochloric acid leaching with stannic ion followed by solvent extraction. Hydrometallurgy 2017, 171, 123-127. [CrossRef]

20. Chen, W.S. The application of organic solvents and thermal process for eliminating EVA resin layer from waste photovoltaic modules. In Proceedings of the IOP Conference Series: Earth and Environmental Science, Seoul, Korea, 26-29 January 2019; Volume 291.

21. Choi, S.; Yoo, K.; Alorro, R.D. Hydrochloric acid leaching behavior of metals from non-magnetic fraction of Pb dross. Geosyst. Eng. 2019, 22, 347-354. [CrossRef] 